\title{
Highly Selective and Sensitive Stripping Voltammmetric Determination of Cobalt with Ammonium 2-Aminocyclohexene-1-dithiocarboxylate and Nitrite
}

\author{
Ali Asghar EnSAFI $I^{\dagger}$ and Sharyar ABBASI \\ College of Chemistry, Isfahan University of Technology, Isfahan, Iran
}

\begin{abstract}
A sensitive stripping voltammetric determination of $\mathrm{Co}$ (II) is described, based on the selective accumulation of its complex with ammonium 2-aminocyclohexene-1-dithiocarbamate on HMDE and subsequent reduction of the complex in the presence of nitrite as a catalyst. The peak potential is about $-1.35 \mathrm{~V} v s . \mathrm{Ag} / \mathrm{AgCl}$ reference electrode at $\mathrm{pH}=10.0$. The calibration graph was linear for the range of $0.01-40 \mathrm{ng} / \mathrm{ml}$, with a limit of detection of $8.0 \mathrm{pg} / \mathrm{ml}$. The relative standard deviation for ten replicate analyses of $1.0 \mathrm{ng} / \mathrm{ml}$ of $\mathrm{Co}$ (II) is $2.6 \%$. The method is very selective and has been applied for the determination of cobalt in natural water and serum samples.
\end{abstract}

(Received August 24, 1999; Accepted December 8, 1999)

Cobalt is a biologically essential trace element. ${ }^{1}$ It serves its paramount function as an essential component of vitamin $\mathrm{B}_{12}$. Although cobalt is required only in minute amounts for maintaining normal health, a lower or higher concentration may lead to deficiency or toxicity states, respectively, resulting in impairment or abnormalities of health. Since the concentration of cobalt is extremely low in tap water and biological samples, a highly sensitive method is necessary for its determination. Many papers have been published on the determination of cobalt in various samples. The investigations have been carried out by various analytical techniques, such as atomic absorption spectrometry, ${ }^{2,3}$ neutron activation analysis, ${ }^{4,5}$ electrophoresis ${ }^{6,7}$ and electrochemical methods. For cobalt determination, different modern polarographic techniques such as differential pulse, stripping voltammetry and adsorption differential pulse voltammetry have been used as well as various cobalt complexes such as those of nioxime, ${ }^{7} \alpha$-benzil dioxime, ${ }^{8}$ dimethylglyoxime, ${ }^{9}$ 1,10-phenanthroline, ${ }^{10}$ diphenylglyoxime, ${ }^{11}$ thiocyanate, ${ }^{12} \quad 2,2^{\prime}$-bipyridine, ${ }^{13}$ and 2 - $\left(5^{\prime}\right.$-bromo- $2^{\prime}$ pyridylazol)-5-diethylaminophenol. ${ }^{14}$ However none of those procedures are sensitive for direct determination of cobalt at sub ppb level, because such levels are comparable to the detection limits of the methods (Table 1). In this paper the catalyticadsorptive stripping voltammetry of the complex of $\mathrm{Co}$ (II) with ammonium 2-amino cyclohexene-1-dithiocarbamate at a hanging mercury drop electrode (HMDE) was investigated.

\section{Experimental}

\section{Reagents and chemicals}

All chemicals were of analytical grade unless otherwise stated. Doubly distilled water was used throughout. The buffers were constructed of a mixture of $0.2 \mathrm{M} \mathrm{NH}_{3}$ and $0.2 \mathrm{M}$ $\mathrm{NH}_{4} \mathrm{Cl}$ solution at suitable ratios.

A standard cobalt solution $(1.00 \mathrm{mg} / \mathrm{ml})$ was prepared by

† To whom correspondence should be addressed. dissolving cobalt(II)-nitrite in distilled water, this mixture was standardized complexometrically by EDTA. Standards of working solutions were made by appropriate dilution as required.

Sodium nitrite solution $(1.5 \mathrm{M})$ was prepared daily by dissolving $10.350 \mathrm{~g} \mathrm{NaNO}_{2}$ (Merck) in water in a $100 \mathrm{ml}$ volumetric flask. Traces of cobalt in blank electrolyte were removed using Chelex-100 resin.

The Chelex 100 was purified by shaking three times with distilled methanol, twice with distilled water, then once with ammonia buffer and finally twice with distilled water.

Ammonium 2-aminocyclohexene-1-dithiocarbamate (AADC) was prepared and purified according to Takeshima et al. ${ }^{15}$ An aliquat $\left(1.0 \times 10^{-3} \mathrm{M}\right)$ of AADC solution was made in water by dissolving $0.0190 \mathrm{~g}$ of the ligand in $100 \mathrm{ml}$ water in a volumetric flask. This solution was prepared daily.

\section{Apparatus}

A PAR Model 384 B polarographic analyzer was employed in connection with a Model 303 SMDE (EG \& G, PAR, USA); a Model DMP 40-44 plotter and a Model 305 stirrer. In all experiments, conventional three electrode system, containing a medium size HMDE with a surface area of $1.8 \mathrm{~mm}^{2}$ as a working electrode, an $\mathrm{Ag} / \mathrm{AgCl}(3 \mathrm{M} \mathrm{KCl})$ reference electrode and platinum wire counter electrode was used. Surface preconcentration of the cobalt complex was achieved using a fast stirring rate and a medium drop size. All potentials reported in this paper are referred to the $\mathrm{Ag} / \mathrm{AgCl}$ electrode. Solutions were de-aerated with pure nitrogen for 4 min prior to each determination.

\section{Serum preparation}

Mineralization of $2 \mathrm{ml}$ of the samples was carried out for $3 \mathrm{~h}$ at $160^{\circ} \mathrm{C}$ in a PTFE vessel with the addition of $4 \mathrm{ml}$ of concentrated nitric acid. Samples containing a high concentration of cobalt were analyzed directly after dilution with water to a suitable volume. Samples containing low concentrations of cobalt were digested by UV irradiation for $3 \mathrm{~h}$ 
Table 1 Comparison of the previous stripping voltammetric and AES methods with the proposed method for the determination of Co(II)

\begin{tabular}{|c|c|c|c|c|c|}
\hline Reagent used & Limit of detection/ng ml ${ }^{-1}$ & Linear range/ng ml ${ }^{-1}$ & RED, \% & Interferent & Ref. \\
\hline Nioxime- $\mathrm{NO}_{2}$ & 19 & $63-630$ & $4 \quad(n=5)$ & $\mathrm{Zn}^{2+}, \mathrm{Ni}^{2+}, \mathrm{Fe}^{3+}$ & 7 \\
\hline$\alpha$-Benzil dioxime & 2.6 & $6.3-630$ & $2.8(n=8)$ & $\mathrm{Zn}^{2+}, \mathrm{Fe}^{3+}, \mathrm{Ni}^{2+}$ & 8 \\
\hline Dimethylglyoxime & 10 & $100-6000$ & $2.5(n=8)$ & $\mathrm{Zn}^{2+}, \mathrm{Mn}^{2+}, \mathrm{Fe}^{2+}, \mathrm{Fe}^{3+}$ & 9 \\
\hline 1,10-Phenanthroline & 1 & $5-1000$ & $2.3(n=8)$ & $\mathrm{Zn}^{2+}, \mathrm{Fe}^{3+}, \mathrm{Ni}^{2+}, \mathrm{Mn}^{2+}$ & 10 \\
\hline Diphenylglyoxime & 200 & $220-2000$ & $2.4(n=6)$ & - & 11 \\
\hline Thiocyanate & 4.5 & $20-5900$ & $1.6(n=10)$ & $\mathrm{Fe}^{2+}, \mathrm{Fe}^{3+}, \mathrm{MoO}_{4}^{-}, \mathrm{Cu}^{2+}, \mathrm{Zn}^{2+}, \mathrm{Sn}^{2+}$ & 12 \\
\hline 2,2'-Bipyridine & 0.6 & $2.9-118$ & $4.9(n=25)$ & $\mathrm{Zn}^{2+}, \mathrm{Ni}^{2+}, \mathrm{Cr}^{3+}, \mathrm{Fe}^{2+}$ & 13 \\
\hline BPDA & 30 & $32-6300$ & $3.5(n=10)$ & $\mathrm{Zn}^{2+}, \mathrm{Ni}^{2+}, \mathrm{Pb}^{2+}$ & 14 \\
\hline $\mathrm{AAE}^{\mathrm{a}}$ & 3 & $3-100$ & $2.7(n=10)$ & - & 3 \\
\hline ICP-AES method & 3 & - & - & - & 20 \\
\hline Proposed method & 0.008 & $0.010-40$ & $2.6(n=10)$ & $\mathrm{Zn}^{2+}$ & \\
\hline
\end{tabular}

BPDA, 2-(5'-bromo-2'-pyridylazol)-5-diethylaminophenol. a. Nitroso-R-salt as a preconcentration reagent.

using $1 \mathrm{~kW}$ lamp after dilution with water to $50 \mathrm{ml}$ and addition of $0.20 \mathrm{ml}$ hydrogen peroxide $(30 \%)$ prior to the cathodic stripping voltammetric analysis. ${ }^{14}$ Samples containing low concentrations of cobalt must be digested by UV for $3 \mathrm{~h}$.

\section{Recommended procedure}

The supporting electrolyte of $0.02 \mathrm{M} \mathrm{NH}_{3} / \mathrm{NH}_{4} \mathrm{Cl}, \mathrm{pH}=10.0$ $(10 \mathrm{ml})$, containing $8.0 \times 10^{-6} \mathrm{M} \mathrm{AADC}$ and $0.30 \mathrm{M} \mathrm{NO}_{2}^{-}$, was pipetted into the cell. The solution was deaerated for $4 \mathrm{~min}$ by bubbling nitrogen. A mercury drop was then dialed on the HMDE and pre-electrolysis was carried out at $-1.2 \mathrm{~V}$ for $60 \mathrm{~s}$ with stirring. After a $5 \mathrm{~s}$ setting period, the solution was cathodically polarized at a scan rate of $12 \mathrm{mV} / \mathrm{s}$ from -1.0 to $-1.5 \mathrm{~V}$. This gave the voltammetric response of the ligand. Then aliquots of the cobalt standard solution (less than $400 \mathrm{ng}$ ) were introduced into the cell while maintaining a nitrogen atmosphere over the solution. The above procedure was repeated to give responses from the $\mathrm{Co}$ (II)-AADC. All data were obtained at room temperature. Calibration graphs were prepared by plotting peak current against $\mathrm{Co}(\mathrm{II})$ concentration. The sample peak current is labeled as $\left(I_{\mathrm{p}}\right)_{\mathrm{s}}$ and the blank peak current as $\left(I_{\mathrm{p}}\right)_{\mathrm{b}}$. The net signal, equal to $\left(I_{\mathrm{p}}\right)_{\mathrm{s}}-\left(I_{\mathrm{p}}\right)_{\mathrm{b}}=\Delta I_{\mathrm{p}}$, was used for construction of a calibration graph.

\section{Results and Discussion}

Ammonium 2-aminocyclohexene-1-dithiocarbamate is a complexing agent with $-N$ and $-S$ donors that is used for the spectrophotometric analysis of $\mathrm{Ni}(\mathrm{II})$ and $\mathrm{Ni}-\mathrm{Co}-\mathrm{Cu}$ mixture by the spectrophotometric method. ${ }^{16-18}$ This paper was the first report about the application of this ligand in voltammetric procedures.

Figure 1 shows the stripping voltammograms for the AACDnitrite, and AACD-nitrite-Co(II) in $0.02 \mathrm{M}$ ammonium buffer solution at $\mathrm{pH}=10.0$. As can be seen in Fig. 1a, for the solution containing AACD-nitrite alone, no obvious current peaks were observable between -1.0 to $-1.5 \mathrm{~V}$, whereas nitrite produces a large reduction current beyond $-1.55 \mathrm{~V} v s$. $\mathrm{Ag} / \mathrm{AgCl}$ electrode. Figure $1 \mathrm{~b}$ shows the stripping voltammogram for the $\mathrm{Co}(\mathrm{II})$ AACD-nitrite system in ammonium buffer $(\mathrm{pH}=10.0)$. The reduction of the adsorbed $\mathrm{Co}$ (II)-AACD complex takes place on HMDE around $-1.35 \mathrm{~V}$ vs. $\mathrm{Ag} / \mathrm{AgCl}$ electrode. When $\mathrm{Co}(\mathrm{II})$ concentration is about $50 \mathrm{ng} / \mathrm{ml}$, no peak current was observed. On the other hand, with the addition of a small amount of nitrite when scanning the electrode potential in the negative direction, a new cathodic peak located at about $-1.35 \mathrm{~V}$ was obtained for cobalt concentration of $6.0 \mathrm{ng} / \mathrm{ml}$. This suggests a catalytic

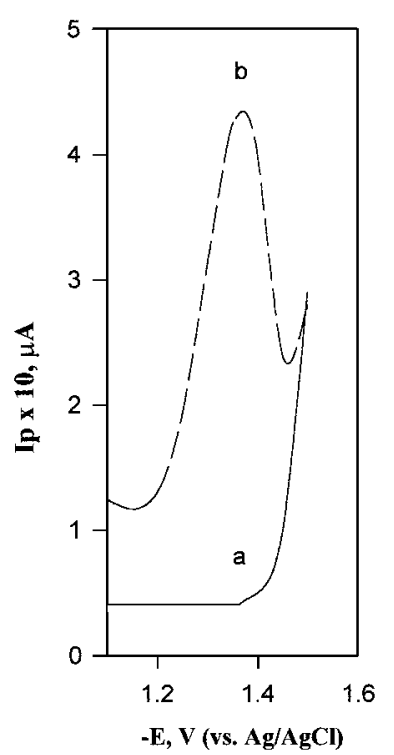

Fig. 1 Stripping voltammogram for (a): AACD- $\mathrm{NO}_{2}{ }^{-}$system at $\mathrm{pH}$ 10; (b): AACD- $\mathrm{NO}_{2}^{-}-\mathrm{Co}(\mathrm{II})$ system at $\mathrm{pH} 10$; conditions: $\mathrm{NO}_{2}^{-}, 0.30$ $\mathrm{M}$; AACD, $8.0 \times 10^{-6} \mathrm{M}$; $\mathrm{Co}(\mathrm{II}), 7.0 \mathrm{ng} / \mathrm{ml}$; scan rate, $12 \mathrm{mV} / \mathrm{s}$; accumulation potential, $-1.20 \mathrm{~V} v s$. $\mathrm{Ag} / \mathrm{AgCl}$; accumulation time, $60 \mathrm{~s}$.

process, because without addition of $\mathrm{Co}(\mathrm{II})$, there is no peak around $-1.35 \mathrm{~V}$ vs. $\mathrm{Ag} / \mathrm{AgCl}$ electrode for the AACD-NO ${ }_{2}^{-}$ system. In addition, as we know, nitrite may disproportionate to nitrate and nitrogen monoxide in aqueous media. ${ }^{19}$ When nitrite was not added, no catalytic current was observed for the electrode process. On the other hand, when nitrate was substituted for nitrite, no obvious peak current for the Co(II)AACD was observed with $50 \mathrm{ng} / \mathrm{ml} \mathrm{Co}$ (II). Thus the intense signal for $\mathrm{Co}(\mathrm{II})-\mathrm{AACD}-\mathrm{NO}_{2}{ }^{-}$system for $6.0 \mathrm{ng} / \mathrm{ml} \mathrm{Co}(\mathrm{II})$ indicates the remarkable sensitivity associated with the catalytic process. The influence of Triton $\mathrm{X}-100$ as a surface-active substance at a concentration of $0.1 \mathrm{mg} / \mathrm{ml}$ causes a $70 \%$ decrease of the catalytic peak. The same effect of surface-active substances such as sodium dodecyl sulfate on the decreasing of the catalytic peak current was observed. On the other hand, the peak current decreased when the temperature increased from 25 to $55^{\circ} \mathrm{C}$. These phenomena show that the complex is strongly adsorbed on HMDE.

\section{Influence of variables}

The effect of $\mathrm{pH}, \mathrm{AACD}$ and nitrite concentration, 


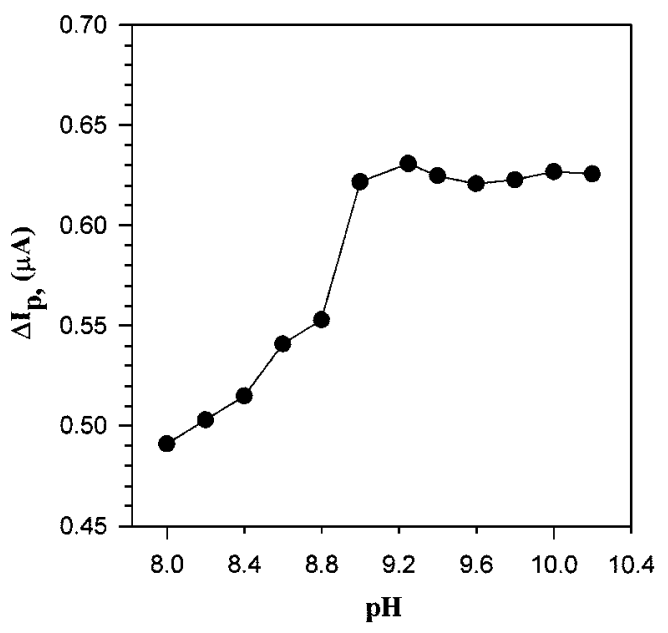

Fig. 2 Influence of $\mathrm{pH}$ on the peak current. conditions: AACD, 4.0 $\times 10^{-5} \mathrm{M} ; \mathrm{NO}_{2}^{-}, 0.10 \mathrm{M} ; \mathrm{Co}(\mathrm{II}), 25.0 \mathrm{ng} / \mathrm{ml}$; scan rate, $20 \mathrm{mV} / \mathrm{s}$; accumulation potential, $-1.1 \mathrm{~V}$; accumulation time, $40 \mathrm{~s}$.

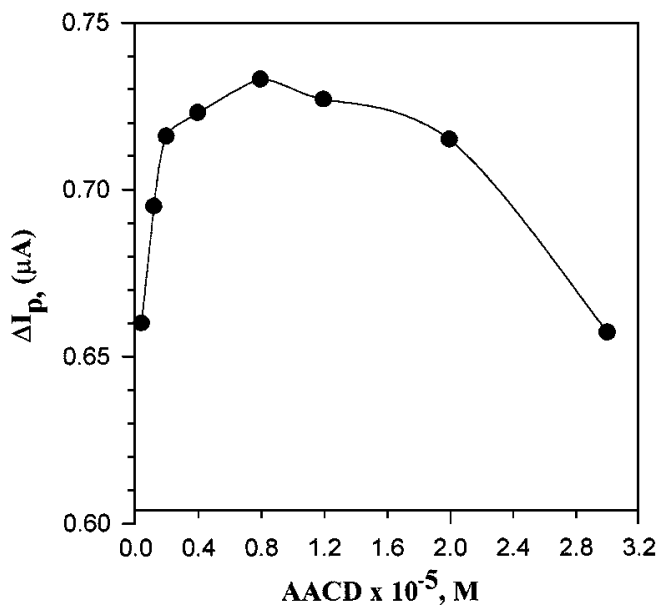

Fig. 3 Effect of AACD concentration on the peak current. Conditions same as Fig. 2 at $\mathrm{pH}$ of 10.0.

accumulation potential, time and scan rate in the sensitivity were studied in the presence of $25 \mathrm{ng} / \mathrm{ml} \mathrm{Co(II)}$ for sample reaction at room temperature.

Our experiments showed that the peak shape was improved in the presence of ammonium chloride. A mixture of ammonia and ammonium chloride was used as a buffer to produced buffers in the $\mathrm{pH}$ range of 8.0 to 10.2. Figure 2 shows the influence of $\mathrm{pH}$ on the peak current. The results show that by increasing $\mathrm{pH}$ up to 9.0 , the peak current increases, whereas from $\mathrm{pH} 9.0$ to 10.2 , the peak current slightly decreased. On the other hand, for $\mathrm{pH}$ values about $8.5-9.5$, the shape of the peak is not suitable (broaden peak produced). Thus a $\mathrm{pH}$ of 10.0 was selected as the optimum for the analysis as this is conveniently buffered by ammonia.

Figure 3 shows the influence of AACD concentration for the range of $0.4-30 \mu \mathrm{M}$. The results show that by increasing AACD concentration up to $8.0 \mu \mathrm{M}$, the current increases, but at ligand concentration above $8.0 \mu \mathrm{M}$, the peak current decreased slightly. This effect is due to the competitive adsorption of AACD.

Variation of the nitrite concentration on peak current for 25

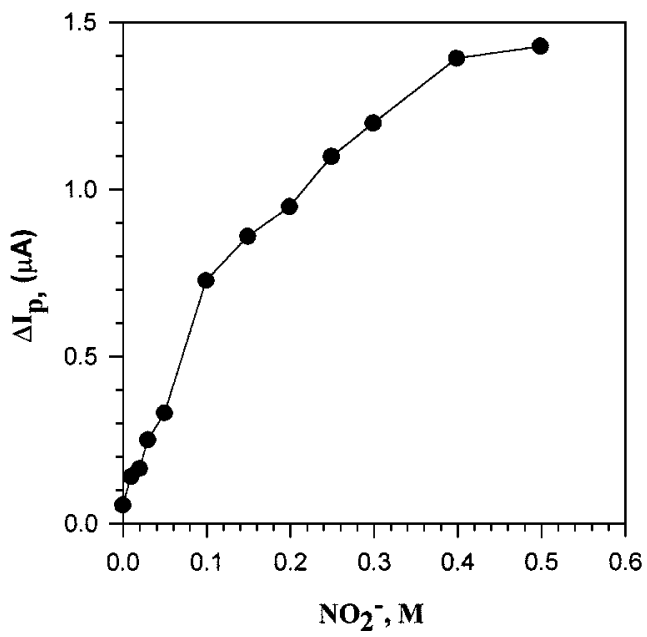

Fig. 4 Influence of nitrite concentration on the peak current. Conditions same as Fig. 2 with $8.0 \times 10^{-6} \mathrm{M}$ AACD at $\mathrm{pH}$ of 10.0

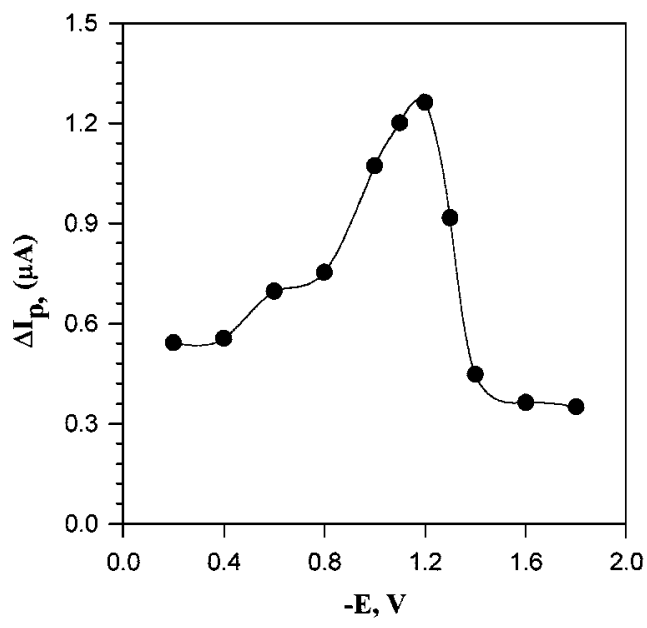

Fig. 5 Influence of accumulation potential on the peak current. Conditions: AACD, $8.0 \times 10^{-6} \mathrm{M}$; $\mathrm{NO}_{2}^{-}, 0.30 \mathrm{M}$; $\mathrm{Co}(\mathrm{II}), 25.0 \mathrm{ng} / \mathrm{ml}$; $\mathrm{pH} 10.0$; scan rate, $20 \mathrm{mV} / \mathrm{s}$; and accumulation time of $40 \mathrm{~s}$.

$\mathrm{ng} / \mathrm{ml} \mathrm{Co}(\mathrm{II})$ in the presence of $8.0 \mu \mathrm{M}$ AACD at $\mathrm{pH}=10.0$ is shown in Fig. 4. The results show that the nitrite concentration had a strong effect on the peak current. With increases in nitrite concentration, the peak current increases at a strong rate. Due to the reduction of nitrite at potentials more negative than -1.5 $\mathrm{V}$, a rather broad reduction peak was observed at higher nitrite concentration of $0.30 \mathrm{M}$. Thus a nitrite concentration of $0.30 \mathrm{M}$ was used for further experiments. In addition, in order to minimize the cobalt concentration in the reagent blank (as an impurity), the nitrite was cleaned with Chelex-100 resin.

Variation of the deposition potential showed that the peak height increased with the deposition potential increasing from -0.2 to $-1.2 \mathrm{~V}$, whereas greater values cause decreasing in peak current (Fig. 5). Therefore, all measurements were carried out using a deposition potential of $-1.2 \mathrm{~V}$.

The influence of deposition time on the peak current showed that the peak current increased linearly with the deposition time within $10-120 \mathrm{~s}$ (Fig. 6). The cathodic stripping voltammetric sensitivity is therefore significantly improved by extending the deposition period. A deposition time of $60 \mathrm{~s}$ was selected by comparison between sensitivity and time of analysis. In 


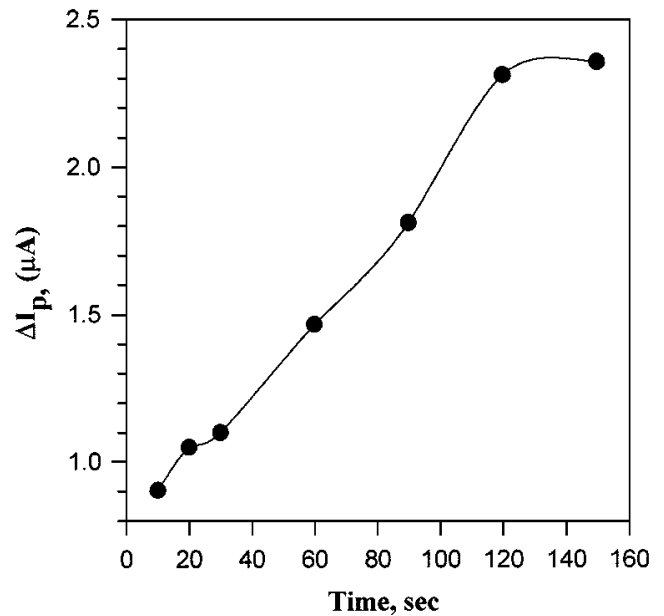

Fig. 6 Influence of accumulation time on the peak current Conditions same as Fig. 5 with accumulation potential of $-1.2 \mathrm{~V}$.

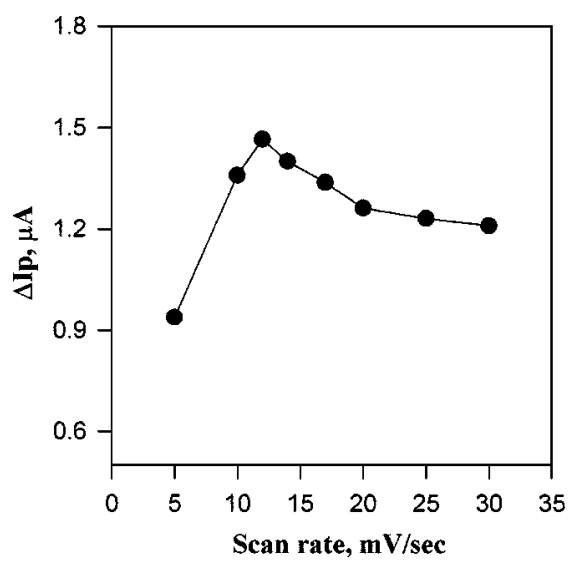

Fig. 7 Effect of scan rate on the sensitivity. Condition same as Fig.5 with accumulation potential of $-1.2 \mathrm{~V}$ and accumulation time of $60 \mathrm{~s}$.

addition, if we select a long accumulation time, the interference effect of potential interfering species in real samples may be increased.

The effect of scan rate on the sensitivity was studied for 25 $\mathrm{ng} / \mathrm{ml} \mathrm{Co(II).} \mathrm{Figure} 7$ shows the influence of scan rate on the peak current. The results show that maximum sensitivity was achieved at a scan rate of $12 \mathrm{mV} / \mathrm{s}$, whereas at a scan rate greater than $12 \mathrm{mV} / \mathrm{s}$, the peak current decreased. Thus a scan rate of $12 \mathrm{mV} / \mathrm{s}$ was selected.

\section{Analytical data}

Under the optimum conditions described before, the calibration graph is linear in the range from 0.01 to $40.0 \mathrm{ng} / \mathrm{ml}$ for accumulation time of $60 \mathrm{~s}$. The regression equation is $\Delta I_{\mathrm{p}}=$ $0.096+61.4 C_{\mathrm{Co(II)}}$ with $r=0.9998$, when $\Delta I_{\mathrm{p}}$ is $\mathrm{nA}$ and $C$ is the Co(II) concentration in $\mathrm{ng} / \mathrm{ml}$. The relative standard deviation for ten replicate measurements of 1.0 and $25.0 \mathrm{ng} / \mathrm{ml}$ of $\mathrm{Co}(\mathrm{II})$ is $2.6 \%$ and $1.6 \%$, respectively.

The detection limit, estimated from the blank signal plus 3 times its standard deviation, was found to be $0.008 \mathrm{ng} / \mathrm{ml}$.

\section{Interference study}

In order to evaluate the selectivity of the proposed method, the influence of 36 foreign ions on the determination of $25 \mathrm{ng} / \mathrm{ml}$
Table 2 Interference study for the determination of Co(II) at the optimum conditions

\begin{tabular}{lc}
\hline \multicolumn{1}{c}{ Added ion } & Tolerance limit \\
\hline $\mathrm{Cs}^{+}, \mathrm{K}^{+}, \mathrm{Li}^{+}, \mathrm{Cu}^{2+}, \mathrm{Mn}^{2+}, \mathrm{Hg}_{2}^{2+} \mathrm{Ba}^{2+}, \mathrm{Ca}^{2+}, \mathrm{La}^{3+}$, & \\
$\mathrm{Cr}^{3+}, \mathrm{Pb}^{2+}, \mathrm{Pd}^{2+}, \mathrm{S}_{2} \mathrm{O}_{8}^{2-}, \mathrm{UO}_{4}^{2-}, \mathrm{B}_{4} \mathrm{O}_{7}^{2-}, \mathrm{HCO}^{-}$, & \\
$\mathrm{WO}_{4}^{2-} \mathrm{CH}_{3} \mathrm{COO}^{-}, \mathrm{ClO}_{3}^{-}, \mathrm{I}^{-}, \mathrm{Br}^{-}, \mathrm{Cl}^{-}, \mathrm{BrO}_{3}^{-}$, & 1000 \\
$\mathrm{~S}_{2} \mathrm{O}_{3}^{2-}, \mathrm{NO}_{3}^{-}, \mathrm{CrO}_{4}^{-}$ & 500 \\
$\mathrm{Th}^{4+}, \mathrm{TeO}_{3}^{2-}, \mathrm{SCN}^{-}, \mathrm{Ce}^{4+}$ & 200 \\
$\mathrm{Cd}^{2+}, \mathrm{Ni}^{2+}, \mathrm{Fe}^{2+}, \mathrm{Fe}^{3+}, \mathrm{IO}_{3}^{-}$ & 75 \\
$\mathrm{Zn}^{2+}$ & \\
\hline
\end{tabular}

Table 3 Analysis of real samples at the optimum conditions

\begin{tabular}{lrrc}
\hline \multicolumn{1}{c}{ Sample } & $\begin{array}{c}\text { Co(II) added/ } \\
\text { ng ml }^{-1}\end{array}$ & $\begin{array}{c}\text { Co(II)found } \\
\text { ng ml }^{-1}\end{array}$ & Recovery, \% \\
\hline River water & 0.0 & $0.23 \pm 0.03$ & - \\
River water & 10.0 & $10.35 \pm 0.05$ & 101.2 \\
River water & 20.0 & $20.40 \pm 0.06$ & 101.0 \\
Tap water & 0.0 & $0.15 \pm 0.02$ & - \\
Tap water & 10.0 & $10.20 \pm 0.03$ & 100.5 \\
Tap water & 20.0 & $20.25 \pm 0.04$ & 100.5 \\
Blood & 0.0 & $0.93 \pm 0.02$ & - \\
Blood & 10.0 & $10.85 \pm 0.04$ & 99.3 \\
Blood & 15.0 & $15.80 \pm 0.06$ & 99.2 \\
\hline
\end{tabular}

a. $n=5$.

Co(II) was studied. The results are shown in Table 2. The results show that the determination of cobalt was free from the interference of $\mathrm{Ni}^{2+}$ up to 200 -fold and $\mathrm{Zn}^{2+}$ up to 75 -fold, which is of particular significance considering their major interference in all of the other adsorptive catalytic voltammetric measurements.

\section{Analysis of real samples}

In order to evaluate the applicability of the method to real sample analysis, the method was applied to determination of cobalt in natural water and human blood with sample pretreatment after addition of different amounts of $\mathrm{Co}$ (II) to them. The cobalt content of human blood after vitamin $B_{12}$ administration was determined using the optimized condition. The results are shown in Table 3.

The catalytic-adsorptive voltammetric method described here is suitable for determining low cobalt concentrations in real samples. However, for serum samples, a thorough mineralization procedure consisting of acid digestion followed by digestion by UV irradiation has to be used to eliminate interferences from residual organic matter. Because the detection limit mainly depends on the cobalt content of the blank, particular attention should be paid to the use of purified reagents.

The present study demonstrates that the catalytic adsorptive stripping voltammetric determination of cobalt is excellent for determination of ultra trace concentration in real samples. The method is inexpensive and is a convenient alternative for high cost mass spectrometry, neutron activation ${ }^{4,5}$ and ICP-AES ${ }^{20}$ analyses. The limit of detection of the method is much lower than that of FIA-preconcentration-atomic absorption spectrometry. ${ }^{3}$

\section{References}

1. I. T. T. Davis, "The Clinical Significance of the Essential Biological Metals", 1972, Thomas, Springfield. 
2. E. D. Caldas, M. F. Gine-Rosias, and J. G. Dorea, Anal. Chim. Acta, 1991, 254, 113.

3. X. Liu and Z. Fang, Anal. Chim. Acta, 1995, 316, 329.

4. G. Nicolaou, R. Pietra, E. Sabbioni, and R. M. Parr, Sci. Total Environ., 1989, 80, 167.

5. J. Y. Yang, M. H. Yang, and S. M. Lin, Anal. Chem., 1990, $62,146$.

6. D. A. Oxspring, T. J. Maxwell, and W. F. Smyth, Anal. Chim. Acta, 1996, 323, 97.

7. A. Bobrowski, Anal. Chem., 1989, 61, 2178.

8. A. Bobrowski and A. M. Bond, Electroanalysis, 1991, 3, 157.

9. M. J. M. Gilbert, H. K. J. Powell, and J. J. Fardy, Anal. Chim. Acta, 1988, 207, 103.

10. V. J. Bebeki and A. N. Voulgaropoulos, Fresenius J. Anal. Chem., 1992, 342, 352.

11. B. Godlewska, J. Golimowski, A. Hulanicki, and C. M. G. Vandenberg, Analyst, 1995, 120, 143.
12. Z. Gao, K. S. Siow, and L. Yeo, Anal. Chim. Acta, 1996, $320,229$.

13. Z. Gao and K. S. Siow, Talanta, 1996, 43, 255.

14. D. A. Oxspring, T. J. Maxwell, and W. F. Smyth, Anal. Chim. Acta, 1996, 323, 97.

15. T. Takashima, A. Yano, N. Fukada, Y. Hirose, and M. Muraoka, J. Chem. Res.(S), 1979, 140.

16. A. Safavi, A. A. Ensafi, and A. Masoumi, Talanta, 1991, 38, 229.

17. A. A. Ensafi, T. Khyammian, and B. Hemmatinejad, Anal. Lett., 1999, 32, 111.

18. T. Khyammian, A. A. Ensafi, and B. Hemmatinejad, Talanta, 1999, 49, 587.

19. D. T. Chow and R. J. Robinson, Anal. Chem., 1953, 25, 1493.

20. R. M. Barnes, "Development in Atomic Plasma Spectrochemical Analysis”, 1981, Heyden \& Sons Inc., 542. 